\title{
Germination and growth of six plant species on contaminated soil with spent oil
}

\author{
*M. Sharifi, Y. Sadeghi, M. Akbarpour
}

Razi University, Centre for Environmental Studies, Department of Biology, Bagh Abrisham, 67149, Kermanshah, Iran

Received 3 February 2007; revised 28 April 2007; accepted 25 July 2007; available online 1 September 2007

\begin{abstract}
Effects of contaminated soil with spent oil on germination, above ground height and biomass of six herbaceous plant species were investigated by conducting a general phytotoxicity test and growth inhibition assessment. Six local plant species were used in order to investigate plant's ability to germinate and survive in a gradient of contaminated soil with spent oil. The species selected for this experiment include one species of Fabaceae (Medicago truncatular), four species of Gramineae (Bromous mermis, Secal seral, Triticum sativa and Agropyron deserterum) and one species of Linaceae (Linum ussitasimum). Inhibitory effect of contaminated soil on germination, height of young seedling and dry weight were measured. In this study an artificial soil with a light texture included $85 \%$ sand, $10 \%$ silt and $5 \%$ clay was used. The exposure to the contaminated soil carried out using four consecutive concentrations (25, 50, 75, $100 \mathrm{~g} / \mathrm{kg}$ ). Results obtained from the current investigation indicate that all species perform dose-dependent responses to the contaminated soils. Reduction in germination, above ground height and biomass for all species were significantly $(\mathrm{P}<0.05)$ different when compared to their controls, however, Medicago truncatular performed the highest and Linum ussitatisimum the lowest inhibitory effect for germination, above ground height and dry weight of seedling.
\end{abstract}

Key words: Spent oil, germination, phytotoxicity test, contaminated soil

\section{INTRODUCTION}

Various petroleum products are common soil contaminants and often contain potentially hazardous chemicals, particularly the polycyclic aromatic hydrocarbons (Huang, et al. 2004). The accumulations of PAHs in soil are due to many anthropogenic sources such as coking plants, solid fuel domestic heating, aircraft exhaust, car exhausts and forest fires (Smith, et al. 2006). Amongst petroleum pollutants spent oil contains heavy metals and polycyclic aromatic hydrocarbons and chemical additives including amines, phenols, benzenes, $\mathrm{Ca}, \mathrm{Zn}, \mathrm{Pb}, \mathrm{Ba}, \mathrm{Mn}, \mathrm{P}$ and $\mathrm{S}$ which are dangerous to living organisms (Meinz, 1999). The spent lubricant, otherwise called waste engine oil, is usually obtained after servicing and subsequent draining from automobile and generator engines. Pollution from spent engine oil is one of the environmental problems and is more widespread than crude oil pollution (Odjegba and Sadiq, 2002). The concentration of PAHs in lubricating oil increases with time of usage and those with two and three rings

*Corresponding Author Email: sharifimozafar@gmail.com Tel./Fax: +98 08314274545 accumulate rapidly in used lubricating oil to very high levels (Vwioko and Fashemi, 2005). Phytoremediation is an innovative technology that uses plants to remove environmental contaminants such as heavy metals and organic compounds. Utilizing plants to absorb, accumulate and detoxify contaminants in the growth substrate through physical, chemical or biological processes is a wide spread practice (eg. White, et al, 2006; Jilani and Khan, 2006). This technology has been applied to both organic and inorganic pollutants present in soil (solid substrate), water (liquid substrate) or the air (Ghosh and Singh, 2005). In medium size cities such as Kermanshah with a population of approximately 600,000 , the main sources of spent oil appears to be small unregulated enterprises. In order to explore more financially acceptable options for biological control of small contaminated sites polluted by spent oil phytoremediation potentials of selected local plant species have been considered as an effective measure. The main aim of this study was to find possible phytoremediation capacity of the local plants in reducing the extent of contaminated soils with spent oil. 


\section{MATERIALS AND METHODS}

Six plant species including Medicago truncatular, Agropyron deserterum, Bromous mermis, Secal seral, Triticum sativa and Linum ussitasimum were screened for their ability to germinate on artificial soil contaminated with spent oil in September 2005. The seeds of these plants were collected from the plants in the pervious growing season. The spent lubricating oil was obtained from an oil car workshop in Kermanshah. An artificial soil was prepared for this experiment containing $85 \%$ sand, $10 \%$ silt and $5 \%$ clay. This light loamy soil provides a suitable substrate for plant growth in phytotoxicity test as has been used by Adam and Duncan (2002), Anoliefo and Vwioko (1995) and avoids anomalies normally associated with natural soils Ghosh and Singh (2005). In order to provide a relatively inert substrate, the artificial soils were placed into autoclave (121 ${ }^{\circ} \mathrm{C}$ ) for 30 minutes in two consecutive days. To obtain an even distribution of spent oil in the soil a mixture of acetone: spent oil (1:1) for each concentration was prepared and mixed with the inert soil by a glass rod. The acetone allowed to evaporating by placing the soil in a laboratory hood. This procedure was used to prepare specimens of 25, 50, 75 and $100 \mathrm{~g}$ of spent oil per kg soil. Uncontaminated controls were prepared by adding only acetone to the soil. Fifty g of uncontaminated soil and soil specimens containing 25, 50, 75 and $100 \mathrm{~g}$ of spent oil $/ \mathrm{kg}$ were prepared in small plastic pots. Each treatment consisted of a set of 20 seeds in three replicates. Seed surface was sterilized prior to use by soaking in a $5 \%$ sodium hypochlorite solutions for five minutes then rinsed three times and soaked in distilled water for 5 minutes. Seeds of each species were planted in small plates and soil moistened with tap water. Plates were placed in dark incubator at $22+2^{\circ} \mathrm{C}$ until the majority of seeds had germinated then were maintained under controlled laboratory conditions. After one or two weeks percentage germination was recorded and the height and dry weight of the plants measured from the soil surface to the terminal bud. The variables measured in the contaminated soils and their controls were expressed as percentage of the control. Statistical significance was determined by single factor analysis of variance (ANOVA) and Tukey test. A probability of 0.05 or lower was considered as significant. In Table 1 to 6 where results of statistical analysis are presented values at each column for control, 25, 50, 75 and 100 $\mathrm{g} / \mathrm{kg}$ soil are designated by A, B, C and D. Values followed by capital or lower case were show nonsignificant or significant different respectively.

\section{RESULTS}

The effects of spent oil on germination rate, above ground height and biomass for Medicago truncatular, Agropyron deserterum, Bromous mermis, Secal seral, Triticum sativa and Linum ussitasimum are shown in Figs. 1 to 6. Generally the various responses of the plant species to the contaminant appear to be dose dependent. The pattern of responses to the contaminant in terms of per cent reduction in germination rate follows an exponential model in all species except $T$. sativa and $S$. seral judging on the basis of coefficient of variations obtained from various fitted curves. Although most plant species demonstrated an overall dose dependent response to the contaminated soil but an increase in germination rate was evident at some concentrations. For example $T$. sativa at 25 and $50 \mathrm{~g} / \mathrm{kg}, S$. seral at $25 \mathrm{~g} / \mathrm{kg}$ and $M$. truncatular at 25,50 and $75 \mathrm{~g} / \mathrm{kg}$ contaminated soil showed an increase in germination rate relative to the control. Moreover, no seed germination was found at $100 \mathrm{~g} / \mathrm{kg}$ spent oil in T. sativa. Statistical comparisons between germination rate, above ground height and biomass measured under various concentration of spent oil for six plant species using single factor analysis of variance (ANOVA) and Tukey test is shown in Tables 1 to 6. Generally, the average percentage of above ground heights responded to the contaminated soils follow an apparent dose dependent reduction most likely similar to an exponential model. However, other species such as $T$. sativa and $A$. deserterum demonstrate a linear reduction. Moreover, $S$. seral at $25 \mathrm{~g} / \mathrm{kg}$ and $M$. truncatular at 25 and $50 \mathrm{~g} / \mathrm{kg}$ soil showed an increase in seedling height. Similar pattern of exponential reduction in biomass was found in other plant species except $T$. sativa, $L$. ussitasimum and $S$. seral which performed a linear reduction. Inhibitory effect of spent oil contaminated soil on germination, height of seedling and above ground biomass in each plant species expressed as $\mathrm{IC}_{50}$ is shown in Fig. 7. 
Int. J. Environ. Sci. Tech., 4 (4): 463-470, Autumn 2007

Table 1: Effect of spent oil on germination and growth of Agropyron deserterum*

\begin{tabular}{llll}
\hline Treatment & Germination (\%) & Seedling height (cm) & Dry biomass (g) \\
\hline Control & $100 \pm 1.7 \mathrm{~A}$ & $9.4 \pm 0.47 \mathrm{~A}$ & $0.02 \pm 0.003 \mathrm{~A}$ \\
25 & $72.5 \pm 1.8 \mathrm{AB}$ & $4.7 \pm 0.57 \mathrm{aB}$ & $0.009 \pm 0.002 \mathrm{aB}$ \\
50 & $57.5 \pm 1.2 \mathrm{aBC}$ & $7.3 \pm 0.59 \mathrm{AbC}$ & $0.01 \pm 0.0008 \mathrm{aBC}$ \\
75 & $26.9 \pm 1.4 \mathrm{abCD}$ & $7.3 \pm 1.09 \mathrm{ABCD}$ & $0.005 \pm 0.0008 \mathrm{aBCD}$ \\
100 & $16.2 \pm 0.33 \mathrm{abcD}$ & $4.87 \pm 1.1 \mathrm{aBCD}$ & $0.002 \pm 0.0006 \mathrm{aBCD}$ \\
\hline
\end{tabular}

Table 2: Effect of spent oil on germination and growth of Bromous mermis *

\begin{tabular}{llll}
\hline Treatment & Germination (\%) & Seedling height (cm) & Dry biomass (g) \\
\hline Control & $100 \pm 1.76 \mathrm{~A}$ & $5.3 \pm 0.33 \mathrm{~A}$ & $0.009 \pm 0.001 \mathrm{~A}$ \\
25 & $80.2 \pm 2.4 \mathrm{AB}$ & $4.35 \pm 0.43 \mathrm{AB}$ & $0.006 \pm 0.001 \mathrm{AB}$ \\
50 & $54.9 \pm 0.3 \mathrm{ABC}$ & $3 \pm 0.38 \mathrm{aBC}$ & $0.002 \pm 0.001 \mathrm{aBC}$ \\
75 & $32.3 \pm 1.2 \mathrm{aBCD}$ & $2.05 \pm 0.43 \mathrm{abCD}$ & $0.002 \pm 0.0005 \mathrm{aBCD}$ \\
100 & $15.04 \pm 0.57 \mathrm{abCD}$ & $2.5 \pm 0.56 \mathrm{aBCD}$ & $0.001 \pm 0.0003 \mathrm{aBCD}$ \\
\hline
\end{tabular}

Table 3: Effect of spent oil on germination and growth of Linum ussitasimum *

\begin{tabular}{llll}
\hline Treatment & Germination (\%) & Seedling height (cm) & Dry biomass (g) \\
\hline Control & $100 \pm 1 \mathrm{~A}$ & $7.75 \pm 0.5 \mathrm{~A}$ & $0.02 \pm 0.001 \mathrm{~A}$ \\
25 & $66.7 \pm 1 \mathrm{aB}$ & $5 \pm 0.6 \mathrm{aB}$ & $0.006 \pm 0.002 \mathrm{aB}$ \\
50 & $33.3 \pm 1.2 \mathrm{abC}$ & $4.2 \pm 1.09 \mathrm{aBC}$ & $0.001 \pm 0.0006 \mathrm{aBC}$ \\
75 & $8.3 \pm 0 \mathrm{abCD}$ & $1.1 \pm 0.5 \mathrm{aBCD}$ & $0 \mathrm{abCD}$ \\
100 & $2.7 \pm 0.33 \mathrm{abCD}$ & $0.7 \pm 0 \mathrm{aBCD}$ & $0 \mathrm{abCD}$ \\
\hline
\end{tabular}

Table 4: Effect of spent oil on germination and growth of Medicago truncatular *

\begin{tabular}{llll}
\hline Treatment & Germination (\%) & Seedling height (cm) & Dry biomass (g) \\
\hline Control & $100 \pm 1.8 \mathrm{~A}$ & $2.1 \pm 0.1 \mathrm{~A}$ & $0.02 \pm 0.002 \mathrm{~A}$ \\
25 & $143 \pm 2 \mathrm{AB}$ & $2.4 \pm 0.08 \mathrm{AB}$ & $0.03 \pm 0.008 \mathrm{AB}$ \\
50 & $119 \pm 2.3 \mathrm{ABC}$ & $2.4 \pm 0.09 \mathrm{ABC}$ & $0.02 \pm 0.05 \mathrm{ABC}$ \\
75 & $115 \pm 0.3 \mathrm{ABCD}$ & $2.1 \pm 0.08 \mathrm{ABCD}$ & $0.01 \pm 0.06 \mathrm{ABCD}$ \\
100 & $63.5 \pm 1.5 \mathrm{AbCD}$ & $1.8 \pm 0.11 \mathrm{AbcD}$ & $0.01 \pm 0.004 \mathrm{ABCD}$ \\
\hline
\end{tabular}

Table 5: Effect of spent oil on germination and growth of Secal seral *

\begin{tabular}{llll}
\hline Treatment & Germination (\%) & Seedling height (cm) & Dry biomass (g) \\
\hline Control & $100 \pm 0.58 \mathrm{~A}$ & $9.7 \pm 0.93 \mathrm{~A}$ & $0.04 \pm 0.002 \mathrm{~A}$ \\
25 & $111 \pm 0.88 \mathrm{AB}$ & $10.3 \pm 0.7 \mathrm{AB}$ & $0.05 \pm 0.066 \mathrm{AB}$ \\
50 & $71.7 \pm 1.2 \mathrm{ABC}$ & $9.2 \pm 0.86 \mathrm{ABC}$ & $0.03 \pm 0.061 \mathrm{ABC}$ \\
75 & $69.2 \pm 1.7 \mathrm{ABCD}$ & $7 \pm 0.78 \mathrm{AbCD}$ & $0.03 \pm 0.004 \mathrm{ABCD}$ \\
100 & $10.8 \pm 0.88 \mathrm{abcd}$ & $9.3 \pm 2.1 \mathrm{ABCD}$ & $0.006 \pm 0.004 \mathrm{abCD}$ \\
\hline
\end{tabular}

Table 6: Effect of spent oil on germination and growth of Triticum sativa *

\begin{tabular}{llll}
\hline Treatment & Germination $(\%)$ & Seedling height $(\mathrm{cm})$ & Dry biomass $(\mathrm{g})$ \\
\hline Control & $100 \pm 0.33 \mathrm{~A}$ & $10.5 \pm 1.6 \mathrm{~A}$ & $0.06 \pm 0.002 \mathrm{~A}$ \\
25 & $184 \pm 0.88 \mathrm{aB}$ & $8.2 \pm 0.56 \mathrm{AB}$ & $0.087 \pm 0.01 \mathrm{AB}$ \\
50 & $134 \pm 2.08 \mathrm{ABC}$ & $7.2 \pm 0.68 \mathrm{ABC}$ & $0.057 \pm 0.01 \mathrm{ABC}$ \\
75 & $70 \pm 0.33 \mathrm{AbCD}$ & $3.7 \pm 1.01 \mathrm{abCD}$ & $0.018 \pm 0.005 \mathrm{abCD}$ \\
100 & $0 \mathrm{abcD}$ & $0 \mathrm{abCD}$ & $0 \mathrm{abcD}$ \\
\hline
\end{tabular}

*Values followed for the all above tables by capital or lower cases were show non-significant or significant different respectively 


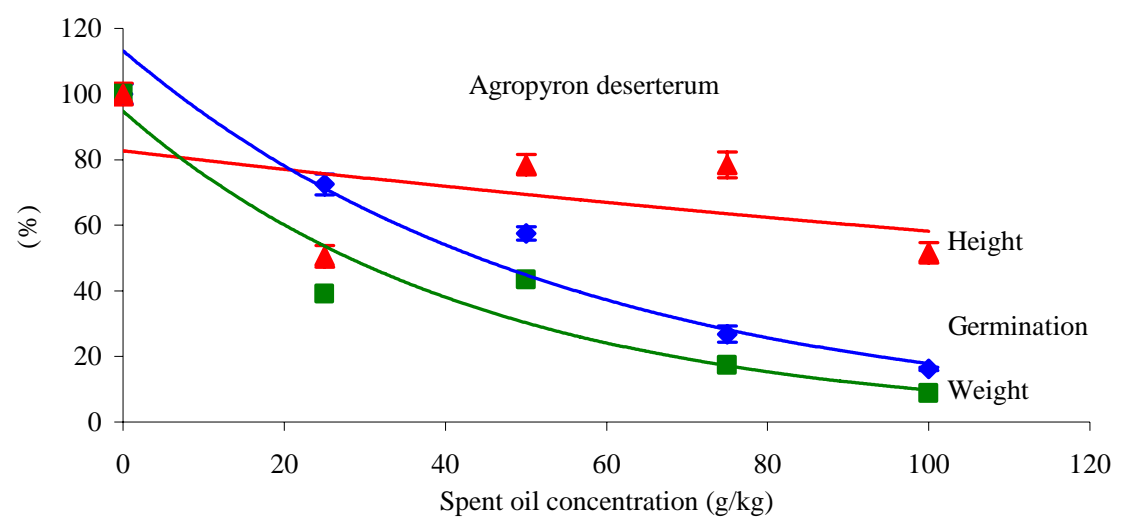

Fig. 1: Effect of spent oil contaminated soil on germination rate, above ground height and biomass of seedling in $M$. truncatular

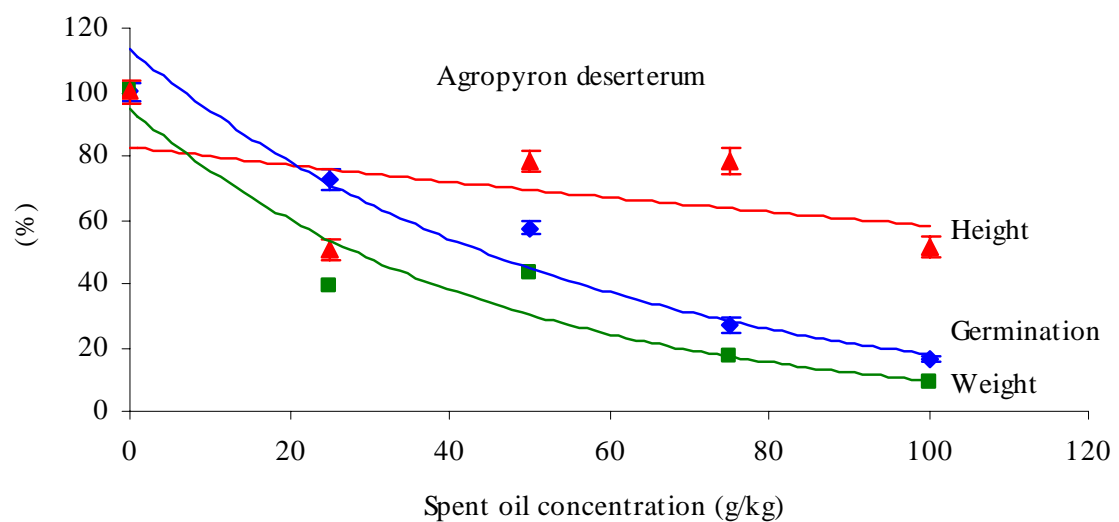

Fig. 2: Effect of spent oil contaminated soil on germination rate, above ground height and biomass of seedling in A. deserterum

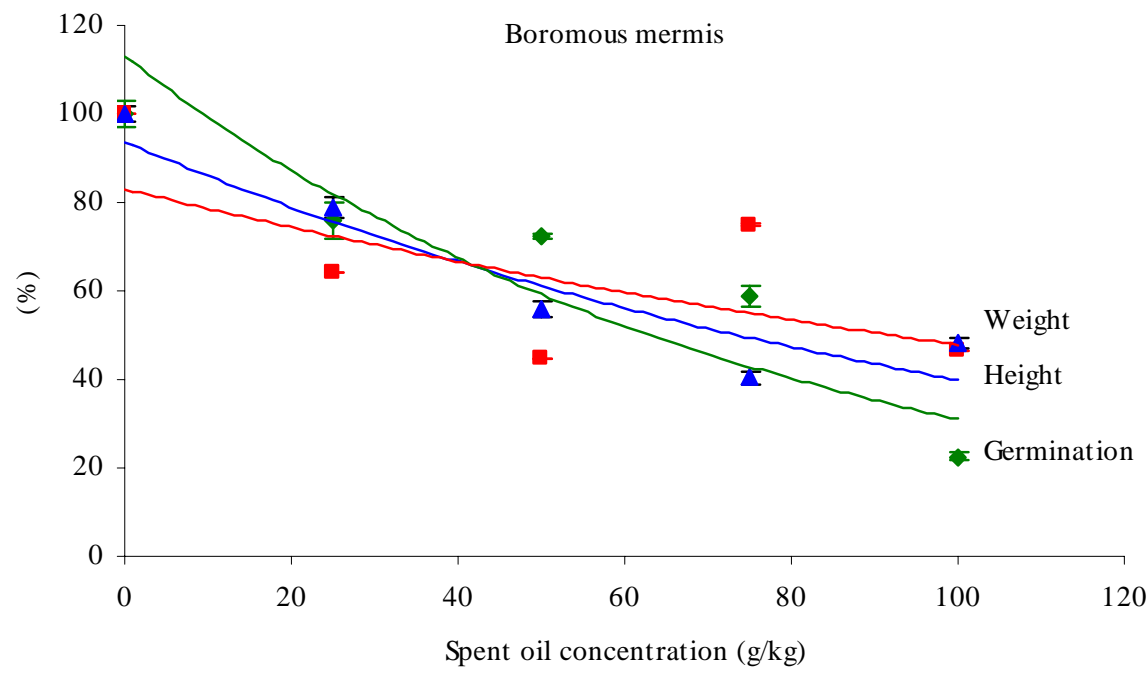

Fig. 3: Effect of spent oil contaminated soil on germination rate, above ground height and biomass of seedling in $B$. mermis 


\section{DISCUSSION AND CONCLUSION}

Results obtained from current experiment are similar to those obtained by Anoliefo and Vwioko (1995). These authors have carried out an experiment using spent lubricating oil in soils supplemented with various concentrations of spent oil ranging from $1-5 \% \mathrm{w} / \mathrm{w}$ and two plant species Capsicum annum and Lycopersicon esculentum. Anoliefo and Vwioko (1995) reported that treatment of soil with 4 and 5 percent spent engine oil consistently inhibited germination of both plants. Also, they considered the mean height and leaf surface area after eighty-four days from sowing reported lowest values at 3\% treatment. Odjegba and Sadiq (2002) also examined effects of spent engine oil on the growth of Amaranthus hybridus and reported significant differences between the control plants and those grown in the oil treated soil. In their experiment the mean height of the control plants was significantly $(\mathrm{p}<0.05)$ greater than those for plants grown in soil treated with 1-5 percent spent engine oil.

Vwioko and Fashemi (2005) have investigated growth response of five different plant species in soil supplemented with spent lubricating oil at 1-6 \% w/w strengths. The result of this experiment which conducted at six consecutive concentrations level showed that various growth parameters demonstrate an overall dose dependent response although at lower concentration some plant species showed a positive response to the contaminant. For parameters such as plant height, stem girth, leaf surface area, fresh and dry weights, and root length, the mean values obtained were higher for $1 \% \mathrm{w} / \mathrm{w}$ than control. Plants in higher concentrations ( $2-6 \% \mathrm{w} / \mathrm{w})$ exhibited depression in growth. Plants grown in $1 \% \mathrm{w} / \mathrm{w}$ spent lubricating oil in soil flowered earlier than those grown in control.

In a similar experiment Adam and Duncan, (2002) have also demonstrated a mixed species specific response to gas oil contamination. In their experiment diesel fuel oil was used as a contaminant in a series of artificial soil with $89 \%$ sand, $4.9 \%$ silt and $8.4 \%$ clay, and two concentration levels of 25 and $50 \mathrm{~g} / \mathrm{kg}$ soil. Plant response was evaluated by percen germination after 14 days exposure. In their experiment Trifolium album, Vicia sativa, Medicago luplina and Trifolium pratense in $25 \mathrm{~g} / \mathrm{kg}$ of contaminated soil showed seed germination nearly equal to control with no fuel oil. Another study Huang, et al., (2004) demonstrated that the germination frequencies of the grass species were all affected by creosote in a concentration dependent manner. Germination of Festuca arundinacea was not affected by $1 \mathrm{~g} / \mathrm{kg}$ creosote in soil but Poa pratensis was able to germinate about $80 \%$. The most sensitive species Elymus canadiensis germinated only $10 \%$ at $1 \mathrm{~g} / \mathrm{kg}$ and $40 \%$ at $0.5 \mathrm{~g} / \mathrm{kg}$ creosote and the higher concentration ( 2 and $3 \mathrm{~g} / \mathrm{kg}$ ) less than $50 \%$ germination was achieved for all grass species.

There is not adequate information regarding the precise mechanisms affecting the reduction in germination rate, above ground biomass and shoot height, however, there are several possible mechanisms suggested by various authors. According to Henner, et al. (1999) some volatile fraction with less than 3 rings are found in spent oil. These compounds are known to have severe inhibitory impact on germination of several plant species. Another group of chemical compounds which are found abundantly in spent oil are polycyclic aromatic compound (PAHs) and has shown to have indirect secondary affects including disruption on plant - water - air relationships (Renault, et al. 2000) and effects on soil microorganisms such as mycorrhizal fungi (Nicolotti and Egli, 1998). Vwioko and Fashemi (2005) have suggested that in experiments exposing plant species to contaminated soil with various petroleum products a reduction in germination rate could be resulted from coating of oil on seed surface, thereby affecting physiological functions within the seed. Various studies have shown that the dynamics of solubilization and ionic exchange in soils have been negatively affected under the influence of spent oil (Odjegba and Sadiq, 2002).

Inhibitory effect of contaminated soil with spent oil as measured by $\mathrm{IC}_{50}$ varies greatly within the plant species examined. The highest $\mathrm{IC}_{50}$ values for germination rate, above ground height and biomass were performed by Medicago truncatular approximating 10 times greater than Linum ussitasimum which showed to be the most sensitive species to the contaminant. All species belonging to Graminae (Agropyron deserterum, Bromous mermis, Secal seral, Triticum sativa) have $\mathrm{IC}_{50}$ values closer to each other. This study demonstrates that $M$. truncatular is the most tolerant plant species amongst the species examined. Although the experiment appears to trigger species specific responses all species showed significant differences when compared to their controls. Similar species specific responses to pollutant stress have also been reported by Lin, et al. (2002). The differential sensitivity of plants to spent oil toxicity 
M. Sharifi, et al.

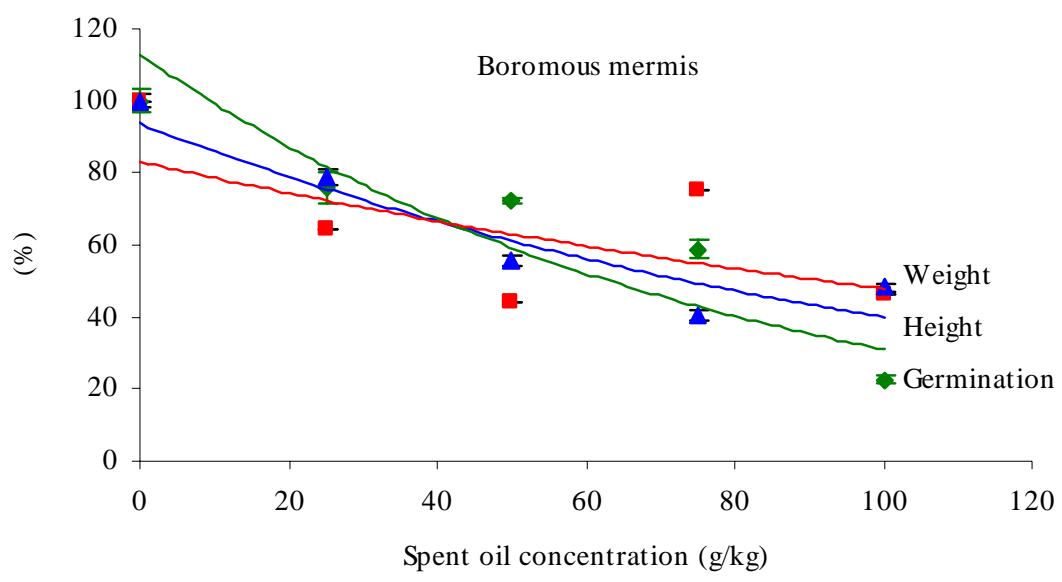

Fig. 4: Effect of spent oil contaminated soil on germination rate, above ground height and biomass of seedling in S.seral

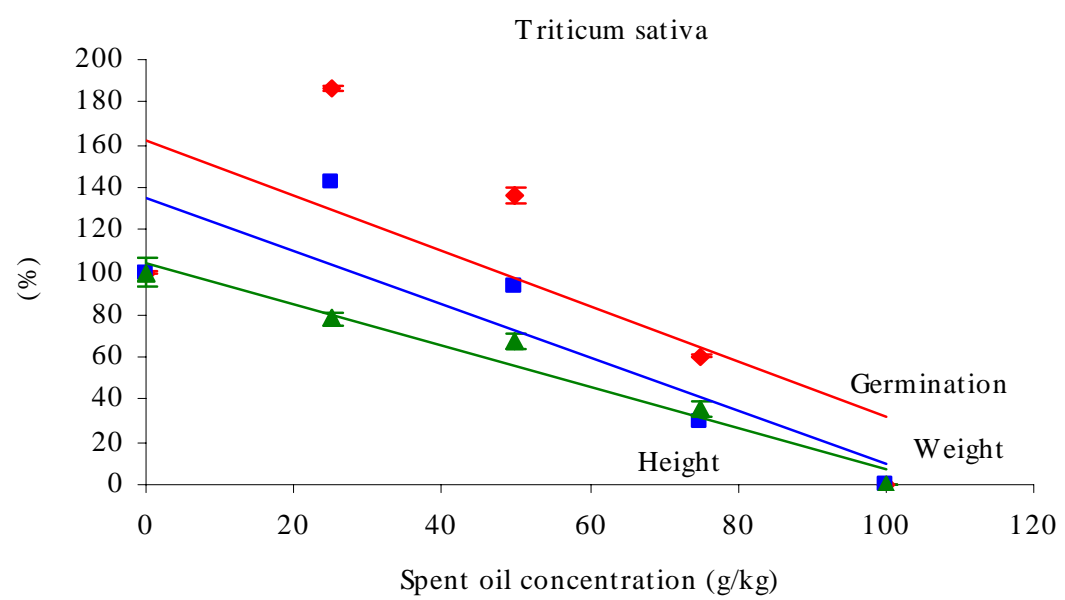

Fig. 5: Effect of spent oil contaminated soil on germination rate, above ground height and biomass of seedling in $T$. sativa

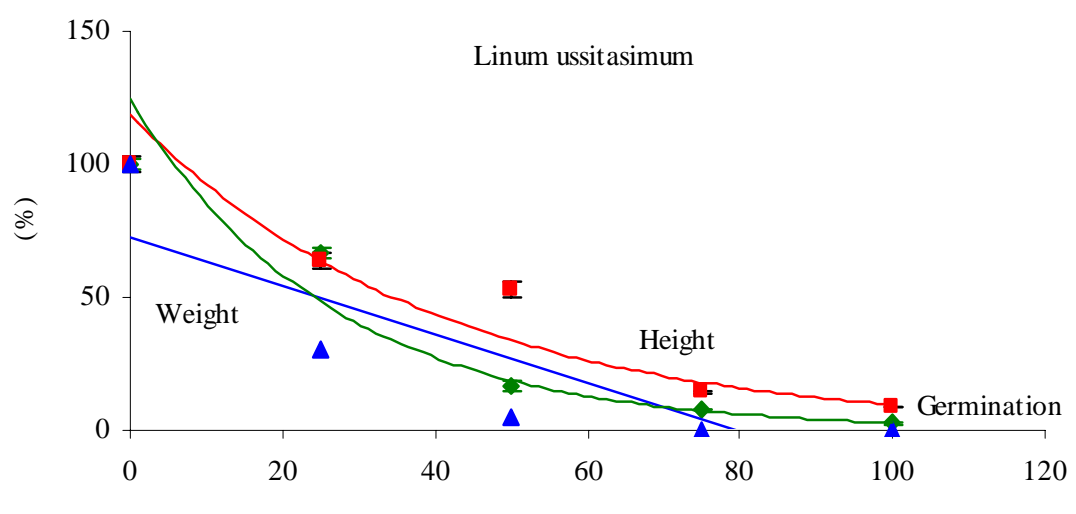

Spent oil concentration $(\mathrm{g} / \mathrm{kg})$

Fig. 6: Effect of spent oil contaminated soil on germination rate, above ground height and biomass of seedling in L. ussitasimum 


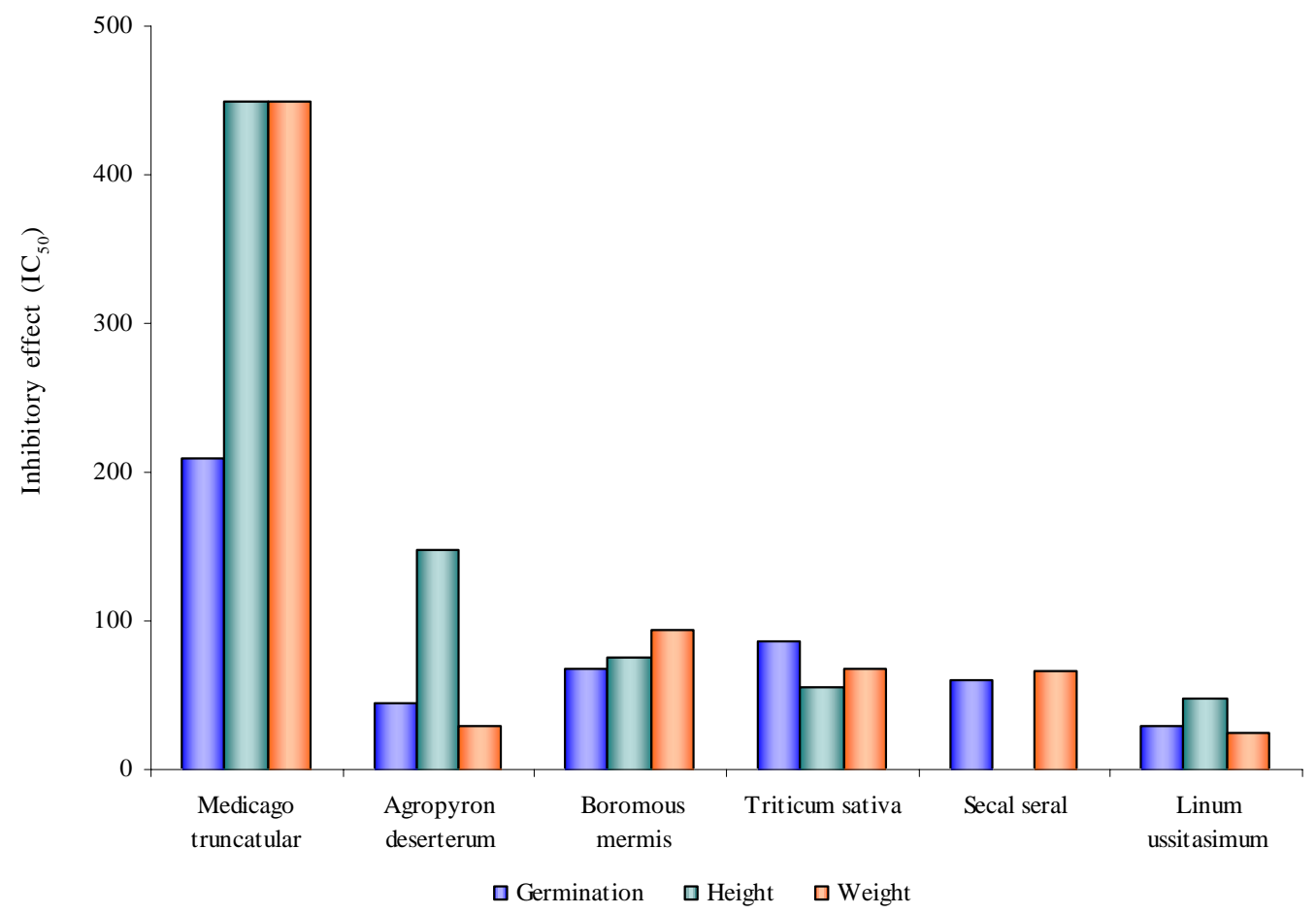

Fig. 7: Inhibitory effect $\left(\mathrm{IC}_{50}\right)$ of spent oil contaminated soil on germination rate, height of seedling and above ground biomass in each plant species.

can be exploited in phytoremediation practice by choosing species that are well tolerant to the contaminant. This is based on their ability to uptake, extract and transfer the pollutant out of contaminated soil. It is possible that the better response of $M$. truncatular compared with the plant species of Gramineae family is due to the ability of the former species in nitrogen fixation. Although it has been shown that in phytoremediation research grasses are usually more efficient than similar size forbs for their fibrous root system with extensive root surface area for microbial colonization and dense rhizospher (Glick, 2003).

\section{ACKNOWLEDGEMENTS}

This study was funded by a grant provided by Kermanshah refinery. The authors wish to express their gratitude to Mr Kavianpour Director of the Research Centre for the Oil Industry and other authorities for their advice and technical assistance.

\section{REFERENCES}

Adam, G.; Duncan, H., (2002). Influence of diesel fuel on seed germination., Environ. Pollut., 10, 363-370.
Anoliefo, G.O.; Vwioko, D.E., (1995). Effects of spent lubricating oil on the growth of Capcicum annum L. and Lycopersicum esculentum miller., Environ. Pollut., 88, 361364.

Ghosh M.; Singh S.P., (2005). A review on phytoremediation of heavy metals and utilization of its byproducts., Appl. Eco. Environ. Res., 3(1), 1-18.

Glick, B.R., (2003). Phytoremediation: synergistic use of plants and bacteria to clean up the environment., Biotechnol. Adv., 21, 383-393.

Henner, P.; Schiavon, M.; Druelle, V.; Lichtfouse, E., (1999). Phytotoxicity of ancient gaswork soils. Effects of polycyclic aromatic hydrocarbons (PAHs) on plant germination. Org. Geochem., 30, 963-966.

Huang, X.D.; Alawi, Y.E.; Penrose, D.M.; Glick, B.R.; Greenberg, B.M., (2004). A multi process phytoremediation system for removal of polycyclic aromatic hydrocarbons from contaminated soils. Environ. Pollut., 130, 465-476.

Jilani, S.; Khan, M.A., (2006). Biodegradation of Cypermethrin by pseudomonas in a batch activated sludge process. Int. J. Environ. Sci. Tech., 3 (4), 371-380, 2006.

Lin, Q.; Mendelssohn, I.A.; Suidan, M.T.; Lee, K.; Venosa, A.D., (2002). The dose-response relationship between no. 2 fuel oil and the growth of the salt marsh grass, Spartina alterniflora. Mar. Pollut. Bullt., 44, 897-902.

Meinz, V., (1999). Used oil characterization study. Washington state departement of ecology solid and hazardous waste program hazardous waste section olympia, Washington 98504-8711. 
Nicolotti, G.; Egli, S., (1998). Soil contamination by crude oil: impact on the mycorhizosphere and on the revegetation potential of forest trees. Environ. Pollut., 99, 37-43.

Odjegba, V.; Sadiq, A.O., (2002). Effects of spent engine oil on the growth parameters, chlorophyll and protein levels of Amaranthus hybridus L. The Environmentalist, 22, 23-28.

Renault, S.; Zwlazek, J.J.; Fung, M.; Tuttle, S., (2000). Germination, growth and gas exchange of selected boreal forest seedlings in soil containing oil sands tailing. Environ. Pollut., 107, 357-365.

Smith, M.J.; Flowers, T.H.; Duncan, H.J.; Alder, J., (2006). Effects of polycyclic aromatic hydrocarbons on germination and subsequent growth of grasses and legumes in freshly contaminated soil and soil with aged PAHs residues. Environ. Pollut., 141, 519-525.

Violeta, T., (2001). Phytoremediation of metal contaminated soils: metal tolerant and metal accumulation in Pelargonium sp. A thesis presented to the faculty of graduate studies of the University of Guelph.

Vwioko, D.E.; Fashemi, D.S., (2005). Growth Response of Ricinus communis L (Castor Oil) in Spent Lubricating Oil Polluted soil. J. Appl. Sci. Environ. Manage., 9(2), 73-79.

White, P.M.; Wolf, D.C.; Thoma, G.J.; Reynolds, C.M., (2006). Phytoremediation of alkylated polycyclic aromatic hydrocarbons in a crude oil contaminated soil. Water, Air, Soil Pollut., 169: 207-220.

\section{AUTHOR (S) BIOSKETCHES}

Sharifi, M., Ph.D., is an associate professor and director of Razi University, Center for Environmental Studies at Department of Biology, Razi University, Kermanshah, Iran. Email: sharifimozafar@gmail.com

Sadeghi, Y., M.Sc., is a graduate student from Department of Biology, Razi University, Kermanshah, Iran. Email:yalda_255@yahoo.com

Akpapour, M., M.Sc., is a graduate student from Department of Biology, Razi University, Kermanshah, Iran. Email:art635@yahoo.com

This article should be referenced as follows:

Sharifi, M.; Sadeghi, Y.; Akpapour, M., (2007). Germination and growth of six plant species on contaminated soil with spent oil . Int. J. Environ. Sci. Tech., 4 (4), 463-470. 